Судакова Елена Павловна

воспитатель

Сторожева Галина Меркурьевна

воспитатель

Калинина Галина Геннадвевна

воспитатель

МБДОУ «Д/С №2 «Сказка»

г. Ядрин, Чувашская Республика

DOI $10.21661 / r-497308$

\title{
КОНСПЕКТ ИНТЕГРИРОВАННОЙ ОРГАНИЗОВАННОЙ ОБРАЗОВАТЕЛЬНОЙ ДЕЯТЕЛЬНОСТИ В СТАРШЕЙ ГРУППЕ ПО ТЕМЕ «ЛЕС»
}

Аннотация: представленный конспект предназначен для закрепления представления детей о диких животных средней полосы, их детенышах; для развития логического мышления и внимания. В педагогической практике конспект могут использовать педагоги ДОУ, студенты дошкольных спещиальностей.

Ключевые слова: познание, дикие животные, бельчонок, ежонок, счет в обратном порядке, логические концовки.

Тема: Лес

Цель: закрепить представления детей о лесе и их обитателях.

Программное содержание:

Уточнять и расширять представление детей о лесе, о разнообразии его растительного мира (кустарников, деревьев, травянистых растений, грибов и ягод), животного мира. Учить детей отгадывать загадки; развивать быстроту мышления, находчивость. Закрепить знания детей о детёнышах животных. Учить решать арифметические задачи в стихах. Упражнять в счёте до 10 в прямом и обратном порядке, в установлении пространственных взаимоотношений между предметами (перед, за, между, рядом). Активизировать словарь детей: бельчонок, ежонок, дикие животные, земляника, перед, за, между, рядом. Воспитывать 
у детей интерес к жизни леса и бережное отношение к нему; умение слушать воспитателя и своих товарищей.

Интегращия по образовательным областям: познавательное развитие, физическое развитие, социально-коммуникативное развитие, речевое развитие.

Материал: макеты деревьев, грибов, ягод; игрушки (волк, заяц, медведь, лиса, ёж); мяч, телеграмма от Лесовика.

Ход занятия

(Дети сидят на стульях.) Воспитатель: Дети сегодня к нам в детский сад пришла телеграмма от старичка Лесовика. Хотите узнать: о чём он в телеграмме пишет?

Дети: Да.

(Воспитатель читает телеграмму.) - Ребята, я узнал от друзей, что в детском саду вы очень много занимаетесь и знаете всё обо всём: о лесе, о его растительном и животном мире. И мне очень захотелось посмотреть и послушать, правда ли мои друзья говорят. Но в лесу сейчас много дел. Поэтому я вам присылаю загадки и задания, а когда лес наденет свой зелёный наряд, приглашаю к себе в лес гости. (Воспитатель читает загадки.)

Дом со всех сторон открыт

Он резною крышей крыт.

Заходи в зелёный дом-

Чудеса увидишь в нём. (Лес.)

Весной веселит, летом холодит,

Осенью питает, зимой согревает. (Дерево.)

Зимой и летом одним цветом. (Ель.)

(По мере отгадывания загадок, предметы появляются в группе и расставляются виде леса.)

Воспитатель: Ребята, как называется место, где растёт много разнообразных деревьев?

Дети: Лес.

Воспитатель: Что ещё растёт в лесу, кроме деревьев? (Oтветь детей.) 
Возле леса на опушке,

Украшая тёмный бор.

Вырос пёстрый, как Петрушка,

Ядовитый (мухомор.)

Под сосною у дорожки

Кто стоит среди травы?

Ножка есть, но нет сапожка,

Шляпка есть, нет головы. (Гриб.) (Воспитатель после каждой отгадки выставляет грибы.)

На припёке у пеньков

Много тоненьких стебельков.

Каждый тонкий стебелёк

Держит алый огонёк.

Разгибаем стебельки-

Собираем огоньки. (Земляника.)

Воспитатель: В лесу живут разные звери. Узнайте, какие?

Сердитый недотрога

Живёт в глуши лесной.

Иголок очень много,

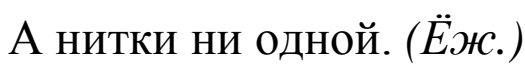

Хитрая плутовка,

Рыжая головка,

Хвост пушистый - краса,

А зовут её... (Лиса.)

Хозяин лесной просыпается весной,

А зимой, под вьюжный вой,

Спит в избушке снеговой. (Медведъ.)

Кто зимой холодный

Бродит злой, голодный? (Волк.)

Что за зверь лесной 
Встал как столбик под сосной.

И стоит среди травы-

Уши больше головы? (Заяц.)

У меня есть дупло,

В нем и сухо, и тепло.

Укрываюсь я хвостом,

Сплю в дупле я сладким сном. (Белка.)

Воспитатель: Получился настоящий лес! Сколько в нём деревьев, грибов, ягод и разных зверей. А у каждого животного есть детёныши. Как же они называются? Давайте поиграем в игру «Назови детёныша» (Воспитатель демонстрирует картинки с изображением диких животных, дети называют животных и их детёныимей).

Ёж - ежонок, лиса - лисёнок, медведь - медвежонок, волк - волчонок, заяцзайчонок, белка - бельчонок.

Bосnитатель: Ребята, чтобы не тревожить животных в их «доме», существуют определенные правила. А вы их знаете? (Воспитатель с детьми вспоминают правила поведения в лесу).

Воспитатель: Как много интересного в лесу. Ёж, лиса, медведь, волк, заяц какие они животные?

Дети: Дикие.

Bоспитатель: А почему их называют дикими? (Ответы детей.)

Воспитатель: Лесные зверюшки хотят с нами поиграть. Давайте посмотрим, где расположился каждое животное? (Повторяют термины, обозначающие пространственное расположение по отномению к другим предметам - перед, за, между, рядом.)

\section{Игра «Что изменилось?»}

Bоспитатель: Дети, сейчас вы закроете глаза, а зверюшки поменяют место расположения, открыв глаза, вы должны угадать - что изменилось? (Игра проводится 2-3 раза.) 
Bоспитатель: Ребята, Лесовик прислал нам еще задания. Зверюшки посидят и посмотрят, как мы будем выполнять их, потом расскажут Лесовику, как мы старательно работали над заданиями.

Воспитатель: Небольшая математическая разминка - игра «Назови соседа». Я передам мяч одному ребёнку и назову цифру, а он должен называть предыдущего и последующего «соседа» заданной цифры.

Воспитатель: (читает телеграмму Лесовика дальще.) - Еще я хочу узнать, как вы умеете решать задачи в стихах.

Ёжик по лесу шёл,

На обед грибы нашёл:

Два под берёзой,

Один - у осины.

Сколько их будет

В плетёной корзине?

Под кустами у реки

Жили майские жуки:

Дочка, сын, отец и мать

Кто их может сосчитать?

Ну-ка, сколько всех ребят

На горе катаются?

Трое в саночках сидят,

Один дожидается.

Bосnитатель: А теперь поиграем в игру «Да и нет» и узнаем, какие вы внимательные. Я опишу вам ситуацию, а вы скажете, бывает ли то, о чём идёт речь: «Волк бродит по лесу», «Волк на дереве сидит», «В кастрюле чашка варится», «Кошка по крыше гуляет», «Лодка по небу плывёт», «Девочка рисует домик», «Домик рисует девочку».

Воспитатель: Следующее задание Лесовика - «Логические концовки»

Если стол выше стула, то стул (ниже стола.)

Если 2 больше одного, то 1 (меньше двух.) 
Если Саша вышел из дома раньше Серёжи, то Серёжа (выщел позже Саши.)

Если река глубже ручейка, то ручеёк (мельче реки.)

Если сестра старше брата, то брат (младше сестры.)

Если правая рука справа, то левая (слева.)

Если красная ленточка длиннее, чем синяя ленточка, то синяя ленточка (короче, чем красная.)

Воспитатель: Ребята, Лесовик сомневается, что вы умеете считать до 10 в прямом и обратном порядке. Как вы думаете, он прав?

Дети: Нет, мы умеем считать.

Воспитатель: Следующее задание «Прямой и обратный счет до 10». (Дети считают грибы в прямом и обратном порядке.)

Воспитатель: Молодцы, дети, вы справились со всеми заданиями старика Лесовика. Какие задания Лесовика вам больше всего понравились? А зверюшки передадут ему, какие вы умные, сообразительные, внимательные. Пришла пора попрощаться с лесом и его обителями. Давайте все вместе громко скажем: «Лес мы твои друзья», тише произнесем: «До новой встречи. Мы тебя никогда не обидим», очень тихо - «Мы будем скучать».

\section{Список литературы}

1. Воронкевич О.А. Добро пожаловать в экологию! - Детство-пресс, 2016.

2. Смирнова В.В. Программа и конспекты занятий / В.В. Смирнова, Н.И. Балуев, Г.М. Парфенов. - СПб: Изд-во РГПУ им. А.И. Герцена: Союз, 2001.

3. Помораева И.А. Формирование элементарных математических представлений в старшей группе / И.А. Помораева, В.А. Позина. - Изд-во Мозаика-Синтез. - М., 2016.

4. Веракса Н.Е. Основная образовательная программа дошкольного образования «От рождения до школы» / Н.Е. Веракса, Т.С. Комарова, М.А. Васильева. - Изд-во Мозаика-Синтез. - М., 2016. 